\title{
Does Lack of Innovation and Absorptive Capacity Retard Economic Growth in Africa?
}

\author{
Steve Onyeiwu*
}

March 2011

\begin{abstract}
This paper reviews the innovative capabilities and absorptive capacities of African countries, and investigates whether they have played significant roles in the region's slow and episodic economic growth. Results from cross-country regressions covering 31 Sub-Saharan African countries suggest that growth in Africa is not simply a question of capital accumulation, fertility rates, aid dependency, and stable macroeconomic environment. It is also about strengthening the capacity of African countries to assimilate and effectively use knowledge and technology. Contrary to the views held by many analysts, the growth of African economies does not depend so much on their ability to innovate, but rather on their capacity to absorb and effectively use new technologies. Beyond technological issues, the paper confirms the stylized facts that the size of the government and political stability are important for the growth performance of African countries.
\end{abstract}

Keywords: growth, innovation, absorptive capacity, technology, Africa

JEL classification: O33, O43, O55

\section{Copyright (C) UNU-WIDER 2011}

*Allegheny College, Meadville, PA, email: sonyeiwu@allegheny.edu

This study has been prepared within the UNU-WIDER project on Africa Development: Myths and Realities, directed by Augustin Fosu.

UNU-WIDER gratefully acknowledges the financial contributions to the project by the Finnish Ministry for Foreign Affairs, and the financial contributions to the research programme by the governments of Denmark (Royal Ministry of Foreign Affairs), Finland (Finnish Ministry for Foreign Affairs), Sweden (Swedish International Development Cooperation Agency—Sida) and the United Kingdom (Department for International Development-DFID). 
Tables appear at the end of the paper.

The World Institute for Development Economics Research (WIDER) was established by the United Nations University (UNU) as its first research and training centre and started work in Helsinki, Finland in 1985. The Institute undertakes applied research and policy analysis on structural changes affecting the developing and transitional economies, provides a forum for the advocacy of policies leading to robust, equitable and environmentally sustainable growth, and promotes capacity strengthening and training in the field of economic and social policy making. Work is carried out by staff researchers and visiting scholars in Helsinki and through networks of collaborating scholars and institutions around the world.

www.wider.unu.edu

publications@wider.unu.edu

UNU World Institute for Development Economics Research (UNU-WIDER)

Katajanokanlaituri 6 B, 00160 Helsinki, Finland

Typescript prepared by Lisa Winkler at UNU-WIDER

The views expressed in this publication are those of the author(s). Publication does not imply endorsement by the Institute or the United Nations University, nor by the programme/project sponsors, of any of the views expressed. 


\section{Introduction}

Is it a myth or reality that Africa's slow economic growth is partly attributable to the continent's weak absorptive capacity (AC) and lack of innovative capability (IC)? 1 Should ineffective science and technology (S\&T) policy be considered part of the 'policy syndromes' (Fosu 2009; Collier and Gunning 1999) that are widely believed to be responsible for Africa's abysmal growth record? This paper discusses the ICs and ACs of African countries, and uses cross-country regressions to explore whether they have played significant roles in inter-country variations in the region's growth performance.

Africa's slow economic growth has been attributed to various factors, none of which surprisingly includes innovation and technology. 2 In explaining inter-country variations in African economic growth, as well as the episodic nature of that growth, analysts often focus on stylized variables such as private investment (Devarajan, Easterly, and Pack 2003), savings and interest rates (Oshikoya 1992), proximity to the tropics (Sachs and Warner 1999), openness of the economy (Hoeffler 2002), and governance (Fosu 2009). Yet, historically, technological change has been the most important source of productivity growth (Scherer 1984). As Moore (1989: 212-13) also points out, 'concern with technological progress as a source of economic growth in the developing world has taken second place in the literature to concern with choice of technology at the level of the firm, and the possibilities of substitution among factors, particularly the substitution of labor for capital'. The role of innovation and technological change has been underplayed by the literature on Africa's economic growth despite evidence from endogenous growth theorists (Romer 1986) and the experiences of the newly industrialized countries (NICs) that technological change does influence economic growth (Amsden 1989).

The non-recognition (at least explicitly) of the potential role of innovation and technology in Africa's growth performance may be attributed to a number of factors. First, innovation and technology are inherently difficult to model, and analysts find it more convenient to regard them asresiduals in growth equations or as part of the socalled 'Africa dummy'.Second, data on Africa's S\&T infrastructure are very spotty, making empirical analysis a very daunting task. Third, many analysts who work on Africa's growth performance have limited knowledge of the literature on 'national systems of innovation' (NIS), and are therefore more prone to regarding technology as exogenous to African economies. 3

This paper is premised on the notion that, difficult as it may seem, we need to begin to investigate the interconnections between $\mathrm{AC}$, technological innovation and Africa's

1 Cohen and Levinthal (1990: 128) define AC as the 'ability of a firm to recognize the value of new, external information (or knowledge), assimilate it, and apply it to commercial ends'.

2 For instance, Collier and Gunning (1999) did not mention technological factors in their list of the various factors that limit growth in Africa (see Table 1).

3 The literature on NIS is dominated by economists who use an interdisciplinary approach to study the impact of S\&T policy on growth, income distribution, industrial development, and international competitiveness. 
growth performance.Such an attempt has the potential to yield policy insights that might be foreclosed under the current approach of analysing Africa's growth performance in terms mainly of stylized variables. For instance, the salience of innovation and AC would imply that African governments should consider using industrial policy to spur growth by correcting distortions, externalities, and other failures in technology and factor markets. It also would mean that the state should facilitate growth by playing a more active role in skill and human resource development. Perhaps more importantly, it would imply that more attention should be paid to brain drain from Africa, which has recently generated debates amongst analysts and policy makers in Africa (Easterly and Nyarko 2008). The paper is structured as follows. Following the introduction in Section 1 , Section 2 reviews the state of scientific and technological development in SubSaharan Africa (SSA). Section 3 discusses the debate on the salience of IC and AC for growth, while Section 4 presents the theoretical model for the paper. Section 5 uses cross-country ordinary least square (OLS) regressions to identify some of the determinants of inter-country variations in Africa's economic growth, and Section 6 consists of the paper's conclusions and policy recommendations.

\section{How weak is Africa's innovativecapability and absorptive capacity, and does it really matter for the region's growth performance?}

A logical starting point for investigating the relationship between technology and growth in Africa is to ascertain the level of technological development of the region. A review of several indicators of S\&T supports the widely held notion that Africa has weak IC and AC relative to other developing regions. Table 2 shows that Africa's share of world expenditure on research and development (R\&D) was a paltry 0.5 per cent in 2001, compared to 15.6 per cent for developing countries as a group, 27.9 per cent for Asia, and 3.1 per cent for Latin America and the Caribbean. Africa's expenditure on $\mathrm{R} \& \mathrm{D}$ as a percentage of GDP has not only been the lowest in the world, but has also been declining over time. In 1990, it was 0.6 per cent, and by 1997 had plummeted to just 0.3 per cent. 4

Table 2 shows that African countries spent an average of US\$6 per person in 2001 on $\mathrm{R} \& \mathrm{D}$ (the lowest in the world), compared to US\$20 for developing countries, US\$46 for Asia, and US\$34 for Latin America and the Caribbean. The table also reveals that Africa accounted for just 1 per cent of researchers in the world, again the lowest. The region's unimpressive scientific and technological performance is more disappointing when the S\&T indicators are disaggregated into various countries as shown in Table 3. As the table shows, most African countries spend less than 0.5 per cent of GDP on $\mathrm{R} \& \mathrm{D}$, compared to 1.4 per cent in China, and 3.2 per cent in South Korea.

Although African countries spend more on their researchers than some developing regions, the region has had the lowest volume of scientific and technical publications. In 2001, for instance, SSA spent US\$49,000 per researcher, compared to Latin America at US\$48,000, and China at US\$38,000 (see Table 2). However, Table 4 shows that other regions have had higher scientific and technical publication levels than Africa. Between

4 Data on science and technology indicators were obtained from the database of the United Nations Educational and Cultural Organization (UNESCO) at www.unesco.org. 
2000 and 2005, the number of scientific and technical publications in Africa grew by just 6 per cent, compared to 119 per cent for East Asia and the Pacific, 36 per cent for Latin America and the Caribbean, 69 per cent for the Middle East and North Africa, and 43 per cent for South Asia. According to data gathered from the UNESCO website, Africa's share of world scientific publications was 1.4 per cent in 1990 and 2000, respectively, compared to 1.7 per cent for Latin America in 1990 and 3.2 per cent in 2000. Asia's researchers accounted for 14.5 per cent of world scientific publications in 1990 and 21.1 per cent in 2000.5

The technological output of African countries, as measured by the number of US patents granted to firms in these countries, also lags behind those of other developing countries (see Table 5). Patent data show that, with the exception of South Africa, Kenya, and Nigeria, most African countries received virtually no patents between 2000 and 2008.6 This is in stark contrast from countries like South Korea, China, India, and Brazil which received thousands of patents within this period. Even when one controls for the relatively small size of African countries, their technological output has been grossly marginal.

There are variations, however, in the levels of IC and AC amongst African countries. Top R\&D spenders, according to Table 3, include Tunisia (1.0 per cent), South Africa (0.9 per cent), and Morocco (0.7 per cent). In terms of the number of researchers per million inhabitants, the leading countries are Tunisia (1,450), South Africa (361), Algeria (170), Seychelles (157), and Cape Verde (127). Tunisia and South Africa are thus the two leading countries in Africa, with regard to expenditure on R\&D and the number of scientists. Notice, also, from Table 3 that these countries achieved respectable levels of economic growth during the 2005-06 period, suggesting that there could be a correlation between AC and growth. South Africa, Kenya, and Nigeria stand out amongst other African countries with regard to the number of patents (see Table 5).

Two critical questions need to be addressed regarding the disappointing technological performance of most African countries. First, to what extent has the poor S\&T infrastructure of African countries affected their growth performance? Does the variation in the levels of technological development of African countries explain intercountry variations in the region's economic growth? The opinion is divided on these questions, as the following section shows.

\section{Should we be concerned about Africa's weak technological capabilities?}

The previous section has shown that Africa has weak technological capabilities, but the extent to which this weakness has affected the region's growth performance is unclear. A review of the literature suggests that there are two broad perspectives on this question.

5 See the UNESCO database on science and technology indicators at www.unesco.org.

6 Based on patent data available at the US Patent Office, about 95 per cent of SSA countries received less than ten patents each during the past 30 years. 


\subsection{Arguments in support of innovativecapability and absorptive capacity for growth in Africa}

Analysts who believe that weak AC and lack of IC have negatively affected the growth performance of African countries use the following arguments to support their position.

\subsubsection{Africa is missing out on growth-inducing foreign investment}

It is believed that foreign investors prefer to locate in economies with an abundant supply of scientists, engineers, and highly skilled workforce. In other words, they prefer economies that are capable of absorbing and assimilating complex technologies. Since FDI is strongly correlated with growth (Ramirez 2000; Chakrabarti 2001; Zhang 2001), it therefore implies that the surfeit of scientists and engineers in a country would spur growth through the attraction of larger flows of FDI. In his interviews with R\&D managers of foreign corporations operating in China, Chen (2008: 628) notes that 'the primary motives underlying the establishment of advanced $R \& D$ centres in China concerned not the cost, but the availability of the required skilled labor'. Corroborating this point, the director of IBM China Research Labs pointed out that:

... the migration is not just about outsourcing for low labour rates. If it were just about low labour rates, we'd probably have R\&D centres in places like Romania and the Philippines. China's advantage is not in low production costs. Production costs are even lower in India. China's advantage lies in the availability of the best talent (Chen 2008: 628).

Because of their lack of technological capability, African countries attract FDI in lowend activities that do not generate substantial value added. FDI flows to Africa go mainly into low-end sectors such as tourism, agriculture, assembly-type manufacturing, mineral extraction, retail trade, and banking (Onyeiwu and Shrestha 2004).

The absolute number of skilled and educated workers in a developing country is one factor that ceteris paribus influences the amount of hightech FDI a developing country can attract. One of the reasons Ireland was able to attract large inflows of high-tech FDI was the relatively large number of engineers and other highly trained people it could provide (Paus 2005: 193).

\subsubsection{Lack of technological capability weakens Africa's export performance}

Growth in Africa has been constrained by weak export performance (UNCTAD 2008). Export performance, in turn, depends on technological capability and AC. Strong IC enables a country to produce high-tech or innovative products that can compete effectively on international markets. Technological capability also increases total-factor productivity, which subsequently enables a country to become cost-competitive abroad (Pack 1993). The experiences of the NICs of South East Asia has shown that export-led industrialization strategies are effective mechanisms for promoting economic growth (Krueger 1997). But an export-led industrialization strategy can only succeed with a strong AC and IC (Kim; Lee and Lee 1987).

\subsubsection{Low absorptive capacity inhibits the growth of manufacturing value added}

Economists who believe in the salience of AC and IC argue that the lack of technological capability and AC by African firms prevents them from generating 
significant levels of manufacturing value added, which has the effect of slowing down the economic growth of African countries. Lall et al. (1994) notes that the failure of Ghanaian firms to develop skills, capabilities, and technical support led to significant and costly deindustrialization in the country during the 1990s. Adei (1990) also found that the failure of the Bonsa Tyre Company in Ghana to enhance its efficiency and productivity was due to the firm's weak technological capability.

\subsubsection{Strong absorptive capacity promotes brain drain,investment in human capital, and economic growth}

Countries with strong AC (for instance, abundant scientists and engineers) usually experience brain drain, as their scientists and engineers seek better opportunities in other countries-particularly in Europe and North America. Easterly and Nyarko (2008) have shown that, rather than having a negative effect on growth, brain drain generates remittances to the country of origin of the migrant. The present value of these remittances typically exceeds the cost of educating the migrant, and thus leads to economic growth. Additionally, the prospect of earning a higher income abroad spurs private investment in human capital, thus enhancing AC and economic growth.

\subsubsection{Historical evidence supports the salience of absorptive capacity and innovative capability}

The history of growth suggests that technological change is a major determinant of growth. In his seminal article on the growth of the US economy, Solow (1956) showed that only about 12.5 per cent of the increase in labour productivity between 1909 and 1949 was due to an increase in capital intensity. The rest was attributable to 'technical change'. The experiences of the NICs have often been used to justify the salience of AC and IC in the growth process (Amsden 1989).

\subsection{Arguments against the salience absorptive capacity and innovative capability}

Those who subscribe to the notion that the lack of technological capability by African countries has not significantly affected the region's growth performance use the following evidence to make their case.

\subsubsection{Oversupply of scientists and engineers in Africa}

Some analysts believe that weak AC cannot be a constraint to Africa's economic growth because there are too many unemployed scientists and engineers in African countries (Sender 1999). According to Amsden (1997), the abundant supply of scientific knowledge in developing countries has failed to generate demand necessary to employ it. Unable to find jobs, scientists and engineers in Africa resort to odd jobs such as cab driving, street hawking, petty trading, etc. According to these analysts, AC can be a constraint to growth only when there are shortages of scientists and engineers in a country. Such is not the case in contemporary Africa.

\subsubsection{Innovation and technology diffuse easily across countries}

A country need not develop indigenous technological capability, as long as it promotes openness of the economy. This argument is based on the fact that technology diffuses to open economies. By crafting effective technology transfer policies, a country can overcome its weak AC and IC. During the Meiji Restoration, Japan adopted FDI polices that allowed it to adapt foreign technologies to local conditions. Japan's rapid growth 
during the post-Second World War era is often attributed to its ability to acquire and effectively assimilate foreign technologies (Lawrence 1990).

\subsubsection{Growth usually precedes absorptive capacity and innovative capability}

There is a chicken or egg dilemma associated with the role of IC and AC in growth. Some have argued that growth has to occur first before a country can mobilize the resources needed to develop strong IC and AC. In the absence of growth, a country may need to borrow money or seek foreign aid in order to invest in R\&D or train scientists and engineers. Resort to borrowing increases a country's external indebtedness, with its negative impact on growth. Research has shown that aid dependency can stifle growth (Moyo and Ferguson 2009).

The arguments for and against the salience of IC and AC all have merit, but empirical analysis is needed to validate some of the contentions. In Section 5, I use cross-country regressions to explore whether differences in AC and IC explain inter-country variations in Africa's growth performance. To provide a theoretical context for the empirical analysis, the next section discusses aspects of endogenous growth models that highlight the salience of IC and AC for economic growth.

\section{Technology, absorptive capacity, and economic growth: a theoretical framework}

Endogenous growth theorists argue that innovation and knowledge are important for growth. Without going into the technical details of this theory, it may be useful to tease out aspects of the theory that are relevant to the explanation of Africa's economic growth. The Romer (1986) endogenous growth model7 can be specified as

$$
\mathrm{Y}=\mathrm{K}^{\alpha}\left(\mathrm{AL}_{\mathrm{Y}}\right)^{(1-\alpha)}
$$

Per capita income can therefore be denoted as

$$
\mathrm{Y} / \mathrm{L}_{\mathrm{Y}}=\mathrm{K}^{\alpha}(\mathrm{A})^{(1-\alpha)}
$$

where $\mathrm{Y}$ represents output, $\mathrm{K}$ capital stock and $\mathrm{L}_{\mathrm{Y}}$ is the labour force required for the production of $\mathrm{Y}$, while A is the stock of knowledge capital in the economy. The capital accumulation function is adapted from the Solow (1956) model

$$
\dot{K}=S_{K} \mathrm{Y}-\Delta \mathrm{K}
$$

where $\mathrm{S}_{\mathrm{K}}$ is the saving rate and $\Delta$ is the rate at which capital is depreciated. The $\mathrm{R} \& \mathrm{D}$ sector can be modelled as

$$
\hat{\mathrm{A}}=ð \mathrm{~L}_{\mathrm{A}}
$$

where $ð$ represents the discovery rate of innovations, with

$$
ð=\delta \mathrm{L}_{\mathrm{A}}^{1-\lambda} \mathrm{A}^{\varnothing}
$$

7 The version of the Romer model used in this paper was adapted and modified from Audretsch and Keilbach (undated). 
$\mathrm{L}_{\mathrm{A}}$ stands for the number of workers involved in the production of new knowledge (i.e. scientists and engineers involved in $R \& D$ ), $\lambda$ denotes returns to scale in $R \& D$, while $\varnothing$ $(0<=\varnothing<=\infty)$ is a parameter that measures the magnitude of knowledge spillovers. All other things are constant, if $\varnothing=0$, the rate of knowledge diffusion will be small and output will be less. Conversely, if $\varnothing=\infty$, the rate of diffusion will be very large and output will be high as well. The rate of knowledge creation (or the rate of endogenous technical change) can be obtained by substituting equation (4) into (3)

$$
\hat{\mathrm{A}}=\delta \mathrm{L}_{\mathrm{A}}{ }^{\lambda} \mathrm{A}^{\varnothing}
$$

It can be seen from equation (5) that the stock of knowledge (and hence economic growth) in the economy depends on the number of workers actively engaged in $R \& D$, returns to scale in $R \& D$, and the rate at which knowledge diffuses in the economy. Contrary to most neoclassical models that assume Arrow-type learning whereby knowledge diffusion is costless and automatic, the rate of technological diffusion depends on the availability of human capital, as well as a strong AC (Lai, Peng, and Bao 2006). If the knowledge generated in the economy is fully commercialized, economic growth will be faster and

$$
A=A_{C}
$$

However, growth will be slower if

$$
A-A_{C}>0
$$

Equation (7) implies that some of the knowledge generated in the economy is not being commercialized. A number of factors may explain the non-commercialization of knowledge in an economy. First, if most of $\mathrm{L}_{\mathrm{A}}$ is concentrated in government labs and other public institutions, much of the knowledge generated will be 'basic knowledge', rather than 'applied knowledge' or applied research. Thus, a country may have a large number of scientists and engineers engaged in $R \& D$, but still experiences slow growth. Second, if property rights are not well-protected in a country, firms will be reluctant to make knowledge available to the public through patenting and other contractual forms in the technology market. Consequently, $\varnothing$ will tend toward zero, leading to both a lower $\mathrm{A}$ and $\mathrm{A}_{\mathrm{C}}$. Third, if firms in an economy lack AC, they may not be in a position to assimilate and commercialize new knowledge. Again, this will slow down the growth process.

\section{An empirical analysis of some of the determinants of inter-country variations in Africa's growth performance}

As Table 6 shows, growth in Africa has not been uniform, both across countries and over time. More revealing in the table is the fact that over half of SSA countries achieved negative average growth rates during the 1990s. At the same time, however, countries such as Cape Verde, Equatorial Guinea, Lesotho, Mauritius, Mozambique, Seychelles, Sudan, and Uganda achieved respectable average growth rates. How might one explain the variation and the episodic nature of growth in Africa? Moss (2007) points out that answers to these questions are not only complex, but are sometimes inexplicable. 
A major goal of this section is to use cross-country regressions to investigate whether $\mathrm{AC}$ and IC explain the differences in the growth performance of African countries. It would be recalled from the theoretical model in the previous section that economic growth depends on four key variables: (i) investment in physical capital, (ii) the labour force, (iii) the volume of technological knowledge generated by the economy (the equivalent of IC), and (iv) the rate by which that knowledge diffuses in the economy (equivalent of AC). The empirical challenge, therefore, becomes that of specifying reduced form growth equations that explicitly incorporate proxies for IC and AC, in addition to stylized variables that affect growth. To the best of my knowledge, most studies on growth in Africa do not explicitly consider innovation and technological variables.

The following growth equation is used in this paper to explore the salience of IC and AC for inter-country variations in the growth performance of Africa.

$\mathrm{GRWT}==\beta_{0}+\beta_{1} A C+\beta_{2} I C+\beta_{3} I N V+\beta_{4} P O P+\beta_{5} P O L R+\beta_{6} O P E N+\beta_{7} G O V$

\subsection{Dependent variable}

Given the boom and bust cycles that characterize growth in Africa, the dependent variable (GRWT) is the average percentage rate of growth of GDP per capita for 31 SSA countries over the 2000-08 period. Table 7 summarizes the variations in the growth of African countries over this period, and shows improvements in the performance of African countries compared to the 1990s (Table 6). 8

\subsection{Explanatory variables}

AC: As equation (5) in the previous section shows, economic growth depends on a country's ability to absorb or assimilate new technologies. ACis particularly crucial for African countries, given their relatively weak capacity to innovate or introduce new technologies. The ideal measure of AC would be the number of scientists and engineers per million of the inhabitants of an African country. However, these data are not available for most African countries. In this paper, ACis proxied by the importation of information and communication technology (ICT) goods as a percentage of total imports. The use of this proxy is based on the assumption that countries with strong AC tend to use ICT more extensively than countries with weak AC. Thus, the higher the number of scientists, engineers, and skilled workers in an economy, the higher its propensity to demand and import ICT goods. The coefficient on AC is expected to be positive.

IC: The ability of a country to innovate and introduce new technologies strengthens its competitiveness in foreign markets. By boosting exports and foreign exchange earnings, technological innovation promotes economic growth. In a study of 204 Korean firms, Young (1992) shows how 96 per cent of these firms succeeded in upgrading their technologies and product quality, and subsequently gained international

8 Some observers attribute the improvements in the growth performance of African countries during the 2000-08 period to economic reform, good governance, and a vibrant global economy that fuelled demand for Africa's exports. This period also witnessed a big surge in the flow of FDI worldwide, including Africa. 
competitiveness. South Korea has been able to sustain a respectable growth rate mainly as a result of the technological capability of Korean firms (Pack and Westphal 1986).IC is measured in this paper by the total number of patents granted each of the 31 countries in my sample during the period 2000-08. The coefficient on this variable is expected to be positive and significant.

\subsection{Investment in physical capital (INV)}

INV spurs growth not only by increasing labour productivity, but also total-factor productivity. Physical capital can also influence growth through its effects on trade (Baldwin and Seghezza 1996; Wacziarg and Welch 2003). Studies on the growth performance of African countries often show that low investment share of GDP is a major reason for the region's slow growth (Levine and Renelt 1992). Investment in physical capital is proxied in this paper by the average annual percentage growth of gross fixed capital formation during the period 2000-08. The coefficient on this variable is expected to be positive.

\subsection{Population growth (POP)}

It is widely believed in the development literature that Africa's high fertility rates may be slowing down the region's growth (Moss 2007). With stagnant or declining output, high fertility rates have the effect of reducing output per head. It may also lead to deficit spending, as the government tries to provide social services needed to support the high dependency ratio that comes with high fertility rates. Population is measured by the annual rate of increase of the population of the sample countries. The coefficient on population is expected to be negative.

\subsection{Political risk (POLR)}

Studies have established a link between political risks, FDI and economic growth. Democratic and politically stable economies attract more FDI than despotic and unstable countries (Schneider and Frey 1985). Since FDI and growth are positively related, political stability then results in faster economic growth. Democratic regimes are also more likely to respect civil liberties, the rule of law and property rightsfeatures that are more conducive to growth and investment. Ngowi (2001) argues that many developing countries have attracted little FDI, and hence have achieved slow growth rates, because they are regarded as 'high risk and are characterized by a lack of political and institutional stability and predictability'. I measure political risk by Freedom House's Index of Political Right. For each of the 31 countries in my sample, I calculated the average of the index for 2000-01. Because the index measures political rights in a scale of 1 to 7 (with 1 representing the highest levels and 7 the lowest), $P O L R$ is expected to be negatively correlated with economic growth.

\subsection{Openness of the economy (OPEN)}

Studies have shown that open economies attract more FDI, and therefore grow faster, than closed economies (Chakrabarti 2001; Morisset 2000; Kandiero and Chitiga 2006). After controlling for endogeneity and country fixed effects, Hoeffler (2002) found that openness is positively correlated with growth in Africa. Removal of capital controls and restrictive trade policies spur local firms to eliminate X-inefficiency and move closer to the international productivity frontier. I measure openness using two indicators: trade as 
a percentage of GDP and FDI inflows as a percentage of GDP. I expect the coefficient on these variables to be positive.

\subsection{Size of the government (GOV)}

The size of the government can affect growth in Africa. As Moss (2007: 94) observes: 'by the early 1980s, it was believed that the cumulative effect of state intervention and unnecessary regulation was a major cause of African economic malaise'. Big government results in rent-seeking activities that crowd out productive investment (Ndulu and O'Connell 1999). They are also a breeding ground for corruption, cronyism, and bureaucratic red tape. Conversely, smaller governments tend to reduce budget deficits, lower interest rates, and hence boost private investment. The size of the government is measured by average general government final consumption expenditure as a percentage of GDP, and its coefficient is expected to be negative.

\subsection{Data sources}

With the exception of patents and political rights, data for the dependent and explanatory variables were collected from the World Development Indicators. The data were computed as averages over the 2000-08 period for 31 SSA countries. Data on patents and political rights were collected from the databases of the US Patent Office and the Heritage Foundation, respectively. The descriptive statistics for the dependent and explanatory variables are summarized in Table 8 . As the table shows, the sample countries had a mean growth rate of about 1.7 per cent during the 2000-08 period, with a maximum of 5.3 per cent, a minimum of -5.9 per cent, and a standard deviation of 2.5 per cent.

\subsection{Results and discussions}

The OLS cross-country regression results are summarized in Table 9. They show that AC, the size of the government, and political stability are significant for inter-country variations in Africa's growth performance. Specifically, a 1 per cent increase in government consumption as a percentage of GDP reduces the growth rate by about 0.12 per cent. By the same token, a 1 per cent increase in the AC of an African country raises the growth rate by about 0.62 per cent. Conversely, a one-point increase in a country's index of political rights (or a deterioration in political rights ranking) reduces growth by about 0.57 per cent, though this effect is relatively weak at the 10 per cent level of significance. Surprisingly, there is no support for the notion that ICs, physical capital, population growth, openness of the economy, or foreign aid explain inter-country variations in the growth performance of African countries.9 The finding on physical capital is consistent with that of Devarajan, Easterly, and Pack (2003), who argue that 'low investment is not the constraint on African development'.

The empirical results imply that growth in Africa is not simply a question of accumulating physical capital, or promoting macroeconomic stability. While good policy is a sine qua non for growth (Collier and Gunning 1999; Fosu 2009), sustainable growth in Africa also requires the strengthening of the AC of African countries. In other

9 In their recent book, Moyo and Ferguson (2009) argue that aid is inimical to the growth and development of African countries. 
words, growth in Africa can be accelerated if African firms succeed in developing the capacity to use technologies developed elsewhere. This result supports what analysts believe to be true: that investment in skills and knowledge is critical for growth in Africa (Schultz 1999).It also implies that African governments should implement measures that would reduce brain drain from Africa. Currently, the brain drain from Africa is occurring at unprecedented levels (Easterly and Nyarko 2008).

Perhaps more revealing from the regression results is the fact that the ability to innovate is not as critical for the growth performance of African countries as the ability to absorb new knowledge and technology.10 African governments, policy makers and development practitioners should, therefore, not take human resource development, skill acquisition, and science/technology education for granted.

The growth-enhancing attributes of technology are not necessarily manifested in the ability of African firms to produce innovative and patentable products. They are manifested in the ability of African firms to use technological knowledge to increase their total factor productivity, as well as move faster along their learning curves. Rather than lead to major innovative breakthroughs, a stronger AC enables African firms to undertake incremental technical change that enhances their competitiveness in global markets (Oyelaran-Oyeyinka 1996).

One reason why economic growth is slow in Africa is because African manufacturing firms produce low-end products that have little or no value added. Quite often, manufactured goods in Africa are simply imported spare parts, raw materials, and other intermediate inputs that were assembled in heavily subsidized factories. Strengthening the AC of African firms would enable them to move into the production of more sophisticated products that have a higher value added.

Beyond the issues of $\mathrm{AC}$ and technological capability, the empirical results in the previous section also confirm two realities about growth in Africa. The first is the notion that big government does undermine the growth of African countries. This result is supported by the fact that African countries experienced their worst growth performance following a phenomenal increase in the size of their governments in the 1970s and 1980s. As Table 6 shows, the average growth rates of most African countries in the 1990s were negative. These unimpressive growth rates can be viewed as consequences of two decades of massive state intervention in African economies. Such a phenomenal growth in bureaucracy was spurred, not by the developmental needs of these countries, but by political and ethnic considerations. The bureaucracy in Africa expanded mainly as a way of providing jobs for those with strong ties to the political and ruling elites. The 1970s and 1980s also corresponded with the era of military dictatorships in Africa, with their penchant for corruption, irresponsible fiscal and monetary policies, as well as misallocation of resources (Ndulu and O’Connell 1999).

The second reality revealed by the empirical results is the fact that political instability is inimical to growth in Africa. One of the reasons for Africa's poor growth performance is the perception of the region as inherently unstable, despite the giant steps recently

10 It would be recalled from the empirical section that the coefficient on patents is not significant. This can be interpreted as implying that the ability to produce innovative products is not as important for growth as the ability to assimilate and use new knowledge and technologies developed elsewhere. 
taken by several African countries to democratize and institutionalize good governance (Sender 1999). As long as this perception persists, Africa's growth performance will continue to fall short of its potential, and lag behind other regions that are favourably perceived by foreign investors and international organizations. African countries, such as Nigeria, Angola, and Libya, with higher rates of return on investment have been able to mitigate this image problem by attracting equity and portfolio investors who are willing to trade risk for high returns.

\section{Conclusions and policy implications}

The preliminary conclusion from the empirical section of this paper is that it does matter for economic growth that Africa has weak AC. However, the ability to innovate is less important for growth in Africa than the ability to assimilate and effectively use new technologies. One major conclusion from this paper is that growth in Africa transcends the issues of capital accumulation, foreign aid, fertility, and stable macroeconomic policies. It is also about developing the capacity of African countries to generate, absorb, and use knowledge in ways that enhance their productivity and international competitiveness.

In addition to addressing the stylized constraints to Africa's economic growth, policy makers and development practitioners should take seriously the need to strengthen the AC of African countries. Although many African countries recognize the need to invest more in science and technical education, they do not seem to have systematic and wellarticulated S\&T policies that focus their efforts on growth-enhancing scientific and technological development. It may, therefore, be necessary to consider S\&T policies as part of the policy syndromes that inhibit growth in Africa.

In designing and implementing growth-enhancing S\&T policies, African countries have a lot to learn from the South Korean example. Of particular relevance to Africa are the creative ways in which the Korean state selectively intervened to strengthen the AC of Korean firms. The Korean example shows that good macroeconomic policy and investment in S\&T are not necessarily antithetical. They both can be designed and implemented in ways that promote sustainable growth in Africa.

\section{References}

Adei, S. (1990). 'Technological Capacity and Aborted Industrialization in Ghana: The Case of Bonsa Tyre Company’. World Development,18 (11): 1501-11.

Amsden, A. (1997). 'Bringing Production Back in Understanding Government's Economic Role in Late Industrialisation’. World Development,4 (4): 469-80.

(1989). Next Giant: South Korea and Late Industrialization.New York: Oxford University Press.

Audretsch, D.B., and M. Keilbach (Undated). 'The Knowledge Spillover Theory of Entrepreneurship and Economic Growth’. Unpublished Manuscript. Jena: Max Planck Institute of Economics.

Baldwin, R., and E. Seghezza (1996). 'Testing for Trade-Induced Investment-Led Growth’. Working Paper 5416.Cambridge, MA: NBER. 
Chakrabarti, A. (2001). 'The Determinants of Foreign Direct Investment: Sensitivity Analyses of Cross-Country Regressions'. Kyklos, 54: 89-114.

Chen, Y.-C. (2008). 'Why Do Multinational Corporations Locate Their Advanced R\&D Centres in Beijing?'. Journal of Development Studies,44 (5): 622-44.

Cohen W.M., and D.A. Levinthal (1990). 'Absorptive Capacity: A New Perspective on Learning and Innovation’. Administrative Science Quarterly,35: 128-52.

Collier, P., and J. Gunning (1999). 'Why Has Africa Grown Slowly?' The Journal of Economic Perspectives,(13) 3: 3-22.

Devarajan, S., W. Easterly., and H. Pack (2003). 'Low Investment Is Not the Constraint on African Development'. Economic Development and Cultural Change,(51) 3: 54771.

Easterly, W., and Y. Nyarko (2008). 'Is the Brain Drain Good for Africa?' Global Working Papers18. Washington, DC: Brookings Institution.

Fosu, A. K. (2009). 'Understanding the African Growth Record: The Importance of Policy Syndromes and Governance'. Discussion Paper2009/02. Helsinki: UNUWIDER.

Hoeffler, A. (2002). 'Openness, Investment and Growth'. Journal of African Economies,(10) 4: 470-97.

Kandiero, T., and M. Chitiga (2006). 'Trade Openness and Foreign Direct Investment in Africa'. SAJEMS,(9) 3: 355-70.

Kim, L., J. Lee, and J. Lee (1987). 'Korea’s Entry into the Computer Industry and its Acquisition of Technological Capability’. Technovation,6: 5-16.

Krueger, A.O. (1997). 'Trade Policy and Economic Development: How We Learn'. American Economic Review,(87) 1: 1-15.

Lai, M., S. Peng, and Q. Bao (2006). 'Technology Spillovers, Absorptive Capacity, and Economic Growth’. China Economic Review,17: 300-20.

Lall, S., G. B. Navaretti, S. Teitel, and G. Wignaraja (1994). Technology and Enterprise Development: Ghana under Structural Adjustment. London: Macmillan.

Lawrence, R. (1990). 'Innovation and Trade: Meeting the Foreign Challenge'. In Eric A. Hanusheket al. (eds), Setting National Priorities: Policy for the Nineties. Washington, DC: Brookings Institution.

Levine, R., and D. Renelt (1992). 'A Sensitivity Analysis of Cross-Country Growth Regressions’. American Economic Review,(82) 4: 942-63.

Morrisset, P. (2000). 'Foreign Direct Investment to Africa: Policies also Matter'. Transnational Corporation,9:107-25.

Moore, F.T. (1983). Technological Change and Industrial Development.Staff Working Paper 613.Washington, DC: World Bank.

Moss, T.J. (2007). African Development.Boulder, CO: Lynne Rienner Publishers.

Moyo, D., and N. Ferguson (2009). Dead Aid: Why Aid is Not Working and How There is a Better Way for Africa.New York: Farrar, Straus, and Giroux. 
Ndulu, B., and S. O’Connell (1999). 'Governance and Growth in Sub-Saharan Africa'. The Journal of Economic Perspectives,(13) 3: 41-66.

Ngowi, H.P. (2001). 'Can Africa Increase its Global Share of Foreign Direct Investment (FDI)?’ West African Review,2:1-22.

Onyeiwu, S., and H. Shrestha (2004). 'Determinants of Foreign Direct Investment in Africa’. Journal of Developing Societies,(20) 2: 89-106.

Oshikoya, T. (1992). 'Interest Rate Liberalization, Savings, Investment and Growth: The Case of Kenya'. Savings and Development,(16) 3: 305-20.

Oyelaran-Oyeyinka, B. (1996). 'Industrial Innovation in Sub-Saharan Africa: The Manufacturing Sector in Nigeria’. Research Policy,22: 1081-96.

Pack, H. (1993). 'Productivity and Industrial Development in Sub-Saharan Africa'. World Development,(21)1: 1-6.

Pack, H., and L. E. Westphal (1986). 'Industrial Strategy and Technology Change: Theory Versus Reality’. Journal of Development Economics,22 (1): 87-128.

Paus, E. (2005). Foreign Investment, Development, and Globalization. New York: Palgrave Macmillan.

Ramirez, M.D. (2000). 'Foreign Direct Investment in Mexico: A Co-integration Analysis'. The Journal of Development Studies, 37:138-62.

Romer, P.M. (1986). 'Increasing Returns and Long-Run Growth'. Journal of Political Economy,94(5): 1002-37.

Sachs, J., and M. Warner (1999). 'Sources of Slow Growth in African Economies'. Journal of African Economies, 16: 335-76.

Scherer, F.M. (1986). Innovation and Growth. Cambridge, MA: MIT.

Schneider, F., and B.F. Frey (1985). 'Economic and Political Determinants of Foreign Direct Investment’. World Development,13:161-75.

Schultz, P.T. (1999). 'Health and Schooling Investments in Africa'. The Journal of Economic Perspectives,(13) 3: 67-88.

Sender, J. (1999). 'Economic Performance Limitations of the Current Consensus'. The Journal of Economic Perspectives,(13) 3: 89-114.

Solow, R. (1956). 'A Contribution to the Theory of Economic Growth'. Quarterly Journal of Economics, 70: 65-94.

UNESCO (1992). Science and Technology in Developing Countries. Paris: UNESCO Publications.

Wacziarg, R., and K. Welch (2003). 'Trade Liberalization and Growth: New Evidence'. Working Paper 10152. Cambridge, MA: NBER.

World Bank (2002). World Development Indicators. Washington, DC: The World Bank.

Young, S.-G. (1992). 'Import Liberalization and Industrial Adjustment'. In V. Corbo and S.M. Suh (eds), Structural Adjustment in a Newly Industrialized Country. Baltimore: The Johns Hopkins University Press. 
Zhang, K.H. (2001). 'Does Foreign Direct Investment Promote Economic Growth? Evidence from East Asia and Latin America’. Contemporary Economic Policy, 19: 175-85.

Table 1: Africa and other developing regions

\begin{tabular}{|c|c|c|}
\hline Growth-limiting factors & Sub-Saharan Africa & Other LDCs \\
\hline \multicolumn{3}{|l|}{ Domestic destiny } \\
\hline $\begin{array}{l}\text { Life expectancy in } 1970 \\
\text { (years) }\end{array}$ & 45.2 & 57.3 \\
\hline Income in 1960 (1985 & 835.5 & 1855.2 \\
\hline \multicolumn{3}{|l|}{ US\$PPP-adjusted } \\
\hline Ethnic fractionalization & 67.6 & 32.7 \\
\hline \multicolumn{3}{|l|}{ Domestic policy } \\
\hline Political rights, 1973-90 & 6.0 & 4.0 \\
\hline Bureaucracy & 1.38 & 1.72 \\
\hline \multicolumn{3}{|l|}{ External destiny } \\
\hline $\begin{array}{l}\text { Population }<100 \mathrm{~km} \text { from the } \\
\text { sea or river (\%) }\end{array}$ & 21.0 & 52.0 \\
\hline Terms of trade volatility & 16.4 & 12.8 \\
\hline \multicolumn{3}{|l|}{ External policy } \\
\hline $\begin{array}{l}\text { Parallel market exchange rate } \\
\text { premium }\end{array}$ & 40.0 & 26.0 \\
\hline Average tariffs $1996-98(\%)$ & 21.0 & 13.0 \\
\hline $\begin{array}{l}\text { Quantitative restrictions, } \\
1988-1990(\%)\end{array}$ & 46.0 & 21.0 \\
\hline \multicolumn{3}{|l|}{ Endogenous } \\
\hline $\begin{array}{l}\text { Growth of GDP per capita, } \\
1965-90\end{array}$ & 0.5 & 1.7 \\
\hline Investment rate in 1997 (\%) & 18.0 & 25.0 \\
\hline $\begin{array}{l}\text { Population growth rate, } 1980 \text { - } \\
97(\%)\end{array}$ & 2.8 & 1.8 \\
\hline $\begin{array}{l}\text { Capital flight/private wealth, } \\
1990(\%)\end{array}$ & 39.0 & 14.0 \\
\hline
\end{tabular}

Source: Collier and Gunning (1999: 7). 
Table 2: Regional science and technology indicators

\begin{tabular}{|c|c|c|c|c|c|c|}
\hline Regions/countries & $\begin{array}{c}\text { GERD* } \\
\text { as \% } \\
\text { World } \\
\text { GERD }\end{array}$ & $\begin{array}{c}\text { GERD } \\
\text { as } \% \\
\text { of } \\
\text { GDP }\end{array}$ & $\begin{array}{c}\text { GERD per } \\
\text { Inhabitant } \\
\text { (PPP } \\
\text { US\$) }\end{array}$ & $\begin{array}{c}\text { Researchers } \\
\text { as a \% of } \\
\text { world total }\end{array}$ & $\begin{array}{c}\text { Researchers } \\
\text { per million } \\
\text { inhabitants }\end{array}$ & $\begin{array}{c}\text { GERD per } \\
\text { researcher } \\
\text { (thousands } \\
\text { of } \\
\text { PPPUS\$) }\end{array}$ \\
\hline $\begin{array}{l}\text { Developing } \\
\text { countries }\end{array}$ & 15.6 & 0.6 & 20 & 28.4 & 347 & 57.9 \\
\hline $\begin{array}{l}\text { Developed } \\
\text { countries }\end{array}$ & 84.4 & 2.2 & 377 & 71.6 & 3,033 & 124.2 \\
\hline Asia & 27.9 & 1.3 & 46 & 34.5 & 537 & 85.1 \\
\hline $\begin{array}{l}\text { Latin America \& } \\
\text { the Caribbean }\end{array}$ & 3.1 & 0.5 & 34 & 6.7 & 715 & 48.2 \\
\hline $\begin{array}{l}\text { SSA (excluding } \\
\text { Arab States) }\end{array}$ & 0.5 & 0.3 & 6 & 1.0 & 113 & 49.1 \\
\hline $\begin{array}{l}\text { Arab States (in } \\
\text { Africa) }\end{array}$ & 0.2 & 0.2 & 7 & 1.5 & 489 & 14.9 \\
\hline $\begin{array}{l}\text { Arab States (in } \\
\text { Asia) }\end{array}$ & 0.1 & 0.2 & 11 & 0.1 & 52 & 211.4 \\
\hline Arab States (All) & 0.4 & 0.2 & 8 & 1.6 & 356 & 23.6 \\
\hline China & 3.9 & 0.6 & 17 & 10.6 & 454 & 38.3 \\
\hline India & 2.0 & 0.7 & 11 & 2.8 & 151 & 75.8 \\
\hline
\end{tabular}

Note: *GERD stands for gross domestic expenditure on research \& development.

Source: Computed from UNESCO statistics published in The State of Science and Technology in the World, Paris (UNESCO Institute of Statistics 2001: 7). 
Table 3: Technology output, absorptive capacity and economic growth for selected African countries (2005)

\begin{tabular}{|c|c|c|c|c|c|}
\hline Country & $\begin{array}{l}\text { R\&D as \% } \\
\text { of GDP* }\end{array}$ & $\begin{array}{l}\text { Researchers } \\
\text { per } 1 \text { million } \\
\text { inhabitants* }\end{array}$ & $\begin{array}{l}\text { Economic } \\
\text { growth in } \\
2005(\%)^{\star \star}\end{array}$ & $\begin{array}{l}\text { Economic } \\
\text { growth in } \\
2006(\%)^{\star *}\end{array}$ & 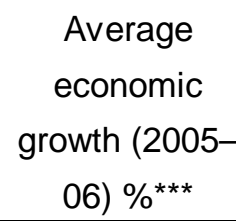 \\
\hline Algeria & 0.1 & 170 & 5 & 2 & 3.5 \\
\hline Botswana & 0.4 & - & 5 & 3 & 4.0 \\
\hline Burkina Faso & 0.2 & 22 & 6 & 6 & 6.0 \\
\hline Cameroon & - & 26 & 2 & 3 & 2.5 \\
\hline Cape Verde & - & 127 & 7 & 11 & 9.0 \\
\hline $\begin{array}{l}\text { Dem. Republic } \\
\text { of Congo }\end{array}$ & 0.5 & - & 6 & 5 & 5.5 \\
\hline Cote d'Ivoire & - & 68 & 1 & 1 & 1.0 \\
\hline Egypt & 0.2 & - & 4 & 7 & 5.5 \\
\hline Ethiopia & 0.2 & 20 & 12 & 11 & 11.5 \\
\hline Gambia & - & 28 & 5 & 7 & 6.0 \\
\hline Lesotho & 0.1 & 10 & 3 & 7 & 5.0 \\
\hline Madagascar & 0.2 & 43 & 5 & 5 & 5.0 \\
\hline Mauritius & 0.4 & - & 5 & 4 & 4.5 \\
\hline Morocco & 0.7 & - & 3 & 8 & 5.5 \\
\hline Mozambique & 0.5 & - & 8 & 9 & 8.5 \\
\hline Niger & - & 8 & 7 & 5 & 6.0 \\
\hline Senegal & 0.1 & - & 6 & 2 & 4.0 \\
\hline Seychelles & 0.4 & 157 & 1 & 5 & 3.0 \\
\hline South Africa & 0.9 & 361 & 5 & 5 & 5.0 \\
\hline Sudan & 0.3 & - & 6 & 11 & 8.5 \\
\hline Tunisia & 1.0 & 1,450 & 4 & 6 & 5.0 \\
\hline Uganda & 0.2 & & 6 & 11 & 8.5 \\
\hline Zambia & 0.0 & 52 & 5 & 6 & 5.5 \\
\hline India & 0.7 & 111 & 9 & 10 & 9.5 \\
\hline China & 1.4 & 926 & 10 & 12 & 11.0 \\
\hline Ireland & 1.3 & 2,882 & 6 & 6 & 6.0 \\
\hline South Korea & 3.2 & 4,162 & 4 & 5 & 4.5 \\
\hline
\end{tabular}

Sources: *UNESCO statistical database; **World Development Indicators ***.

Computed by the author. 
Table 4: Regional distribution of number of scientific and technical publications (2000-05)

\begin{tabular}{|c|c|c|c|c|c|c|c|c|}
\hline Region & 2000 & 2001 & 2002 & 2003 & 2004 & 2005 & $\begin{array}{c}\text { Average } \\
2000-- \\
05\end{array}$ & $\begin{array}{c}\text { Growth } \\
\text { rate, } 2000- \\
05(\%) \\
\end{array}$ \\
\hline East & 20,116 & 22,818 & 25,101 & 30,812 & 37,075 & 44,064 & 29,998 & 119 \\
\hline \multicolumn{9}{|l|}{ Asia \& } \\
\hline \multicolumn{9}{|l|}{ Pacific } \\
\hline LAC & 14,786 & 15,776 & 17,126 & 17,889 & 19,361 & 20,045 & 17,497 & 36 \\
\hline MENA & 3,689 & 4,017 & 4,379 & 5,154 & 5,551 & 6,243 & 4839 & 69 \\
\hline South & 10,796 & 11,334 & 12,262 & 13,162 & 14,086 & 15,429 & 12,845 & 42 \\
\hline \multicolumn{9}{|l|}{ Asia } \\
\hline SSA & 3,355 & 3,279 & 3,438 & 3,331 & 3,517 & 3,563 & 3,413 & 6 \\
\hline World & 629,230 & 628,047 & 637,041 & 660,304 & 687,174 & 708,086 & 658,314 & 13 \\
\hline
\end{tabular}

Source: World Development Indicators database. 
Table 5: Number of us patents granted to selected African and other developing countries (2000-08)

\begin{tabular}{|c|c|c|c|c|c|c|c|c|c|c|}
\hline Country & 2000 & 2001 & 2002 & 2003 & 2004 & 2005 & 2006 & 2007 & 2008 & Total \\
\hline Benin & 0 & 0 & 0 & 0 & 0 & 0 & 0 & 1 & 0 & 1 \\
\hline Cameroon & 0 & 0 & 0 & 0 & 0 & 0 & 0 & 1 & 0 & 1 \\
\hline $\begin{array}{l}\text { Cote } \\
\text { d'Ivoire }\end{array}$ & 0 & 0 & 0 & 0 & 1 & 0 & 0 & 0 & 0 & 1 \\
\hline Gabon & 0 & 0 & 0 & 0 & 0 & 0 & 0 & 1 & 0 & 1 \\
\hline Ghana & 0 & 0 & 0 & 0 & 0 & 0 & 0 & 1 & 0 & 1 \\
\hline Kenya & 3 & 4 & 1 & 10 & 16 & 10 & 3 & 1 & 4 & 62 \\
\hline Mauritius & 0 & 0 & 0 & 0 & 0 & 0 & 0 & 0 & 1 & 1 \\
\hline Namibia & 1 & 0 & 0 & 0 & 0 & 0 & 0 & 0 & 1 & 2 \\
\hline Nigeria & 2 & 1 & 4 & 4 & 1 & 0 & 0 & 1 & 1 & 14 \\
\hline South & 125 & 137 & 123 & 131 & 115 & 108 & 127 & 116 & 124 & 1106 \\
\hline \multicolumn{11}{|l|}{ Africa } \\
\hline Uganda & 0 & 1 & 1 & 0 & 0 & 0 & 0 & 0 & 0 & 2 \\
\hline Costa & 8 & 12 & 8 & 10 & 10 & 13 & 26 & 17 & 13 & 117 \\
\hline \multicolumn{11}{|l|}{ Rica } \\
\hline Dominican & 5 & 0 & 1 & 0 & 0 & 2 & 2 & 2 & 3 & 15 \\
\hline \multicolumn{11}{|l|}{ Republic } \\
\hline India & 131 & 180 & 267 & 356 & 376 & 403 & 506 & 578 & 672 & 3469 \\
\hline Indonesia & 14 & 10 & 15 & 12 & 23 & 23 & 16 & 15 & 19 & 147 \\
\hline Brazil & 113 & 125 & 112 & 180 & 161 & 98 & 148 & 118 & 133 & 1188 \\
\hline $\begin{array}{l}\text { China } \\
\text { (excluding }\end{array}$ & 161 & 265 & 390 & 424 & 597 & 565 & 970 & 1235 & 1874 & 6481 \\
\hline \multicolumn{11}{|l|}{ Hong } \\
\hline \multicolumn{11}{|l|}{ Kong) } \\
\hline South & 3472 & 3763 & 4009 & 4132 & 4671 & 4591 & 6509 & 7264 & 8731 & 47142 \\
\hline Korea & & & & & & & & & & \\
\hline
\end{tabular}


Table 6: GDP per capita (in constant 2000 US\$)

\begin{tabular}{|c|c|c|c|c|c|c|}
\hline & 1960 & 1970 & 1980 & 1990 & 2000 & 1990s avg. growth \\
\hline Angola & & & 928 & 878 & 715 & $-2.0 \%$ \\
\hline Benin & 278 & 308 & 314 & 300 & 362 & $1.9 \%$ \\
\hline Botswana & 254 & 436 & 1.247 & 2.487 & 3,135 & $2.3 \%$ \\
\hline Burkina Faso & 148 & 162 & 181 & 197 & 231 & $1.6 \%$ \\
\hline Burundi & 92 & 118 & 126 & 148 & 100 & $-3.8 \%$ \\
\hline Cameroon & 458 & 448 & 638 & 665 & 587 & $-1.2 \%$ \\
\hline Cape Verde & & & & 886 & 1,222 & $3.3 \%$ \\
\hline $\begin{array}{l}\text { Central African } \\
\text { Republic }\end{array}$ & 346 & 348 & 316 & 275 & 256 & $-0.7 \%$ \\
\hline Chad & 251 & 233 & 152 & 195 & 177 & $-1.0 \%$ \\
\hline Comoros & & & 420 & 435 & 366 & $-1.7 \%$ \\
\hline Congo, Dem. Rep. & 324 & 327 & 252 & 205 & 89 & $-8.0 \%$ \\
\hline Congo, Rep. & 617 & 702 & 957 & 1,109 & 934 & $-1.7 \%$ \\
\hline Cote d'Ivoire & 532 & 840 & 945 & 705 & 670 & $-0.5 \%$ \\
\hline Djibouti & & & & 1,246 & 830 & $-4.0 \%$ \\
\hline Equatorial Guinea & & & & 705 & 2,928 & $15.3 \%$ \\
\hline Eritrea & & & & & 155 & na \\
\hline Ethiopia & & & & 95 & 102 & $0.7 \%$ \\
\hline Gabon & 1,658 & 3,105 & 4,698 & 4.097 & 3,920 & $-0.4 \%$ \\
\hline Gambia, The & & 285 & 333 & 328 & 321 & $-0.2 \%$ \\
\hline Ghana & 281 & 296 & 239 & 214 & 254 & $1.7 \%$ \\
\hline Guinea & & & & 367 & 420 & $1.4 \%$ \\
\hline Guinea-Bissau & & 178 & 144 & 183 & 158 & $-1.5 \%$ \\
\hline Kenya & 213 & 239 & 357 & 379 & 347 & $-0.9 \%$ \\
\hline Lesotho & 111 & 151 & 312 & 391 & 493 & $2.3 \%$ \\
\hline Liberia & 698 & 844 & 747 & 179 & 173 & $-0.3 \%$ \\
\hline Madagascar & 389 & 409 & 349 & 281 & 250 & $-1.2 \%$ \\
\hline Malawi & 97 & 119 & 158 & 143 & 166 & $1.5 \%$ \\
\hline Mali & & 195 & 233 & 193 & 223 & $1.5 \%$ \\
\hline Mauritania & 203 & 353 & 326 & 304 & 355 & $1.6 \%$ \\
\hline Mauritius & & & 1,564 & 2,522 & 3.727 & $4.0 \%$ \\
\hline Mozambique & & & 175 & $15 I$ & 208 & $3.30 / 0$ \\
\hline
\end{tabular}




\begin{tabular}{|c|c|c|c|c|c|c|}
\hline Namibia & & & 1,967 & 1,606 & 1,802 & $1.2 \%$ \\
\hline Niger & 321 & 325 & 273 & 197 & 167 & $-1.6 \%$ \\
\hline Nigeria & 291 & 344 & 409 & 337 & 332 & $-0.1 \%$ \\
\hline Rwanda & 243 & 231 & 282 & 257 & 235 & $-0.9 \%$ \\
\hline $\begin{array}{l}\text { Sao Tome and } \\
\text { Principe }\end{array}$ & & & & 336 & 314 & $-0.7 \%$ \\
\hline Senegal & 507 & 469 & 417 & 428 & 459 & $0.7 \%$ \\
\hline Seychelles & 2,379 & 2,646 & 4.531 & 5,644 & 7,619 & $3.0 \%$ \\
\hline Sierra Leone & 220 & 281 & 289 & 256 & 126 & $-6.8 \%$ \\
\hline South Africa & 2,105 & 3,049 & 3,436 & 3,058 & 2,910 & $-0.5 \%$ \\
\hline Sudan & 288 & 267 & 283 & 281 & 388 & $3.3 \%$ \\
\hline Swaziland & & 727 & 986 & 1,336 & 1,336 & $0.0 \%$ \\
\hline Tanzania & & & & 267 & 269 & $0.1 \%$ \\
\hline Togo & 188 & 316 & 383 & 310 & 291 & $-0.6 \%$ \\
\hline Uganda & & & & 177 & 253 & $3.6 \%$ \\
\hline Zambia & 528 & 569 & 476 & 389 & 328 & $-1.7 \%$ \\
\hline Zimbabwe & 430 & 570 & 562 & 602 & 570 & $-0.5 \%$ \\
\hline
\end{tabular}

Note:Blank cells indicate no data available. No data available for Somalia.

Source:World Bank (2002). 
Table 7: Inter-country variations in growth of GDP per capita in SSA (2000-08

\begin{tabular}{|c|c|c|c|c|c|c|c|c|c|c|}
\hline Country & 2000 & 2001 & 2002 & 2003 & 2004 & 2005 & 2006 & 2007 & 2008 & $\begin{array}{l}\text { Period } \\
\text { average }\end{array}$ \\
\hline Angola & 0.244089 & 0.161806 & 11.02018 & 0.120549 & 7.81584 & 17.1139 & 15.29194 & 17.09027 & 11.82888 & 8.974 \\
\hline Benin & 2.561591 & 1.645041 & 1.065215 & 0.437449 & -0.32172 & -0.45992 & 0.472246 & 1.298421 & 1.836703 & 0.936 \\
\hline Botswana & 6.502947 & 3.740742 & 2.062609 & 5.09605 & 5.371549 & 3.495002 & 1.726112 & 2.95579 & -2.22438 & 3.125 \\
\hline Burkina Faso & -1.20325 & 3.341943 & 1.37561 & 4.592841 & 1.340911 & 3.099254 & 2.380972 & 0.660289 & 1.504066 & 1.881 \\
\hline Burundi & -2.32423 & 0.030144 & 1.932556 & -3.90989 & 1.813058 & -2.05455 & 2.009157 & 0.500887 & 1.441987 & -0.06232 \\
\hline Cameroon & 1.771618 & 2.073056 & 1.586584 & 1.637693 & 1.375628 & 0.079339 & 1.066531 & 1.500104 & 1.892378 & 1.442548 \\
\hline Cape Verde & 4.674273 & 1.964746 & 2.797876 & 4.423876 & -2.31533 & 4.876618 & 9.15301 & 5.406982 & 4.472311 & 3.939374 \\
\hline \multicolumn{11}{|l|}{ Central African } \\
\hline Republic & 0.315277 & -1.50615 & -2.18353 & -9.01487 & -0.56162 & 0.736164 & 2.210655 & 2.314382 & 0.939726 & -0.75 \\
\hline Chad & -4.34492 & 7.623495 & 4.492476 & 10.52384 & 28.93018 & 4.366855 & -2.93399 & -2.55047 & -3.134 & 4.774829 \\
\hline Comoros & -1.21375 & 1.170614 & 1.973637 & 0.333253 & -2.32372 & 2.052218 & -0.92212 & -1.87638 & -1.40384 & -0.24557 \\
\hline $\begin{array}{l}\text { Cong. Dem. } \\
\text { Rep. }\end{array}$ & -9.05242 & -4.63458 & 0.567876 & 2.650234 & 3.374268 & 4.536278 & 2.272443 & 3.267545 & 3.20994 & 0.687954 \\
\hline Cong. Rep & 5.553603 & 1.532017 & 2.283674 & -0.8083 & 1.110569 & 5.316869 & 4.120497 & -3.3922 & 3.699694 & 2.15738 \\
\hline Cote d'Ivoire & -6.09791 & -2.31923 & -3.54027 & -3.57459 & -0.29222 & -0.87719 & -1.50905 & -0.55727 & -0.11165 & -2.09771 \\
\hline $\begin{array}{l}\text { Equatorial } \\
\text { Guinea }\end{array}$ & 10.13103 & 57.22622 & 16.0932 & 10.80357 & 34.24308 & 6.80296 & -1.42591 & 18.26256 & 8.426275 & 17.84033 \\
\hline
\end{tabular}




\begin{tabular}{|c|c|c|c|c|c|c|c|c|c|c|}
\hline Eritrea & -16.2272 & 4.641386 & -1.269 & -6.7641 & -2.69344 & -1.35013 & -4.45997 & -1.80677 & -1.15279 & -3.45356 \\
\hline Ethiopia & 3.276875 & 5.471711 & -1.11108 & -4.67611 & 10.65981 & 8.951254 & 8.011744 & 8.250979 & 8.467924 & 5.255901 \\
\hline Gabon & -4.16102 & -0.14115 & -2.39409 & 0.371015 & -0.66981 & 1.025614 & -0.73164 & 3.603276 & 0.207012 & -0.3212 \\
\hline Gambia & 1.891968 & 2.287759 & -6.37005 & 3.525999 & 3.802559 & 2.018833 & 3.515032 & 3.368421 & 3.040641 & 1.897907 \\
\hline Ghana & 1.243056 & 1.556479 & 2.071982 & 2.792041 & 3.231849 & 3.580941 & 4.128017 & 3.88425 & 4.017138 & 2.945084 \\
\hline Guinea & -0.07525 & 2.011802 & 2.2621 & 0.153852 & 0.769219 & 1.306095 & 0.093702 & -0.63607 & 5.995637 & 1.320121 \\
\hline Guinea Bissau & 5.078914 & -2.16292 & -9.35928 & -9.43047 & -3.04076 & -0.19057 & 1.109767 & -1.62835 & 0.458455 & -2.12947 \\
\hline Kenya & -1.96543 & 1.128432 & -2.02457 & 0.290753 & 2.376609 & 3.053859 & 3.620489 & 4.175821 & 0.902434 & 1.284266 \\
\hline Lesotho & 2.887282 & 1.68444 & 0.51793 & 2.981707 & 3.697489 & -0.08044 & 7.338714 & 4.491334 & 3.381192 & 2.988849 \\
\hline Liberia & 17.85415 & -1.73033 & 0.329687 & -33.0732 & -0.16147 & 1.839322 & 3.55144 & 4.687005 & 2.410034 & -0.47704 \\
\hline Madagascar & 1.68668 & 2.956788 & -15.1565 & 6.707339 & 2.341062 & 1.734901 & 2.173461 & 3.391485 & 4.047422 & 1.098073 \\
\hline Malawi & -1.3582 & -7.53017 & -6.88011 & 3.631472 & 3.053451 & -0.02196 & 5.452311 & 5.874488 & 6.946882 & 1.018685 \\
\hline Mali & 0.329976 & 8.902275 & 1.121403 & 4.268205 & -0.85523 & 2.915368 & 2.156531 & -0.24875 & 1.886035 & 2.275091 \\
\hline Mauritania & -1.06231 & -0.07284 & -1.82349 & 2.567344 & 2.223065 & 2.56542 & 8.744443 & -0.62522 & .. & 1.564552 \\
\hline Mauritius & 3.009046 & 4.412629 & 1.834927 & 2.127237 & 3.805854 & 3.739325 & 2.795169 & 4.035722 & 4.660126 & 3.380004 \\
\hline Mozambique & -1.40574 & 9.104684 & 6.12134 & 3.451868 & 5.367455 & 5.988359 & 6.408739 & 5.015121 & 4.46609 & 4.946435 \\
\hline Namibia & 1.364069 & -0.59463 & 3.210346 & 2.848197 & 10.84615 & 1.216163 & 5.741196 & 2.381486 & 1.01778 & 3.114528 \\
\hline Niger & -4.88713 & 3.36126 & -0.57213 & 0.800175 & -4.2374 & 3.71898 & 2.160568 & -0.03558 & 5.964216 & 0.69699 \\
\hline
\end{tabular}




\begin{tabular}{|c|c|c|c|c|c|c|c|c|c|c|}
\hline Nigeria & 2.67069 & 0.47012 & -1.00076 & 7.577976 & 7.921812 & 2.898398 & 3.731488 & 4.102635 & 2.963698 & 3.481784 \\
\hline Rwanda & 1.108015 & 3.900803 & 8.027684 & -1.39479 & 3.69739 & 5.046027 & 4.749597 & 5.152522 & 8.183147 & 4.274488 \\
\hline Sao Tome \& & & & & & & & & & & \\
\hline Principe & .. & .. & 9.666209 & 3.634604 & 4.820877 & 3.935759 & 4.953101 & 4.063372 & 3.867024 & 4.991564 \\
\hline Senegal & 0.506866 & 1.875609 & -1.93023 & 3.928725 & 3.178296 & 2.894545 & -0.27436 & 1.928061 & -0.17106 & 1.326273 \\
\hline Seychelles & 3.326711 & -2.35661 & -1.80783 & -4.86416 & -2.49718 & 6.95196 & 6.124299 & 6.71985 & 1.259501 & 1.428503 \\
\hline Sierra Leone & 1.262001 & 14.39299 & 22.61792 & 4.849493 & 3.292852 & 3.444432 & 4.006681 & 3.896412 & 2.42769 & 6.687831 \\
\hline South Africa & 1.606285 & 0.872932 & 2.675366 & 1.868776 & 3.628581 & 3.745286 & 4.213257 & 4.088172 & 1.29202 & 2.665631 \\
\hline Sudan & 5.919805 & 3.893944 & 3.219693 & 5.023688 & 3.012526 & 4.134069 & 8.90674 & 7.745232 & 5.944513 & 5.311134 \\
\hline Swaziland & 8.29087 & -0.17437 & 1.017027 & 3.258498 & 1.856651 & 1.353729 & 1.75831 & 2.190254 & 1.057511 & 2.289831 \\
\hline Tanzania & 2.463467 & 3.528144 & 4.463361 & 2.886361 & 3.874373 & 4.447012 & 3.78411 & 4.139564 & 4.401726 & 3.776458 \\
\hline Togo & -3.91964 & -3.06844 & 1.335707 & 0.087706 & 0.440847 & -1.31287 & 1.316085 & -0.61651 & -1.37354 & -0.79007 \\
\hline Uganda & 2.412681 & 1.685993 & 3.05578 & 3.087559 & 3.391017 & 2.922625 & 7.226094 & 5.09412 & 6.007088 & 3.875884 \\
\hline Zambia & 0.937783 & 2.384841 & 0.388174 & 3.34468 & 3.109053 & 2.814729 & 3.716739 & 3.660484 & 3.427493 & 2.642664 \\
\hline Zimbabwe & -8.52783 & -3.06612 & -4.51651 & -10.3465 & -3.6622 & -5.16933 & .. & .. & .. & -5.88142 \\
\hline
\end{tabular}


Table 8: Descriptive statistics

\begin{tabular}{lccccc}
\hline Variable & Observations & Mean & Std. Dev. & Minimum & Maximum \\
\hline GRWT & 31 & 1.66 & 2.43 & -5.88 & 5.31 \\
INV & 31 & 8.60 & 9.25 & -6.58 & 43.02 \\
POP & 31 & 2.21 & 0.83 & 0.08 & 3.78 \\
GOVT & 31 & 15.20 & 7.26 & 6.39 & 45.35 \\
FDI & 31 & 3.52 & 3.33 & 0.6 & 15.00 \\
AID & 31 & 9.85 & 8.06 & 0.34 & 31.45 \\
POLR & 31 & 4.80 & 1.57 & 1.00 & 7.00 \\
TECH & 31 & 4.97 & 2.04 & 1.7 & 12.20 \\
PATENT & 31 & 38.54 & 198.41 & 0 & 1106 \\
\hline
\end{tabular}

Table 9: Results of cross-country OLS regression Dependent variable: growth of GDP per capita (Average 2000--08)

\begin{tabular}{ccccc}
\hline $\begin{array}{c}\text { Explanatory } \\
\text { variables }\end{array}$ & Coefficient & Standard error & $\mathrm{t}$ & $\mathrm{P}>[\mathrm{t}]$ \\
\hline INV & 0.015 & 0.054 & 0.29 & 0.772 \\
POP & 0.584 & 0.658 & 0.89 & 0.384 \\
GOVT & $-0.125^{\star \star}$ & 0.055 & -2.27 & 0.034 \\
FDI & 0.201 & 0.147 & 1.37 & 0.185 \\
AID & 0.012 & 0.065 & 0.19 & 0.852 \\
POLR & $-0.503^{\star}$ & 0.283 & -1.77 & 0.090 \\
TECH & $0.646^{\star \star *}$ & 0.249 & 2.59 & 0.017 \\
PATENT & -0.002 & 0.002 & -0.98 & 0.338 \\
CONS & 0.607 & 2.065 & 0.29 & 0.771
\end{tabular}

Number of $\quad$ R-squared $=\quad F(8,22)=2.99 \quad$ Prob $>F=0.019 \quad$ Root MSE $=1.97$ Observations $=\quad 0.52$ 31 Adj R-squared = 0.35

Note: ${ }^{\star \star \star}$ Significant at the $1 \%$ level; ${ }^{\star \star} 5 \%$ level and $* 10 \%$ level. 